CZASOPISMO INŻYNIERII LĄDOWEJ, ŚRODOWISKA I ARCHITEKTURY JOURNAL OF CIVIL ENGINEERING, ENVIRONMENT AND ARCHITECTURE

JCEEA, t. XXXIII, z. 63 (2/II/16), kwiecień-czerwiec 2016, s. 371-382

Kamil Błażej POCHWAT ${ }^{1}$

Daniel SEY Ś

\title{
BADANIA CZUŁOŚCI MODELU ZBIORNIKA RETENCYJNEGO Z WYKORZYSTANIEM WSKAŹNIKA POJEMNOŚCI INFORMACYJNEJ HELLWIGA
}

\begin{abstract}
Projektowanie obiektów retencyjnych jest złożonym procesem inżynierskim. Wymaga on zebrania szczegółowych danych hydrologicznych zlewni i hydraulicznych systemu kanalizacyjnego, które następnie podlegają szczegółowej analizie. Przeprowadzenie pełnej analizy czynników decydujących o niezbędnej pojemności retencyjnej zbiornika często wymaga opracowania szczegółowego modelu obiektu badań, którym jest zbiornik retencyjny. W artykule przedstawiono wyniki badań dotyczące analizy czułości modelu kanalizacyjnego zbiornika retencyjnego wód deszczowych. Wyniki badań pozwoliły na wskazanie parametrów, które w największym stopniu wpływają na wielkość niezbędnej pojemności retencyjnej zbiornika. Zaplanowane analizy wykonano w oparciu o analizę wskaźnika pojemności informacyjnej Hellwiga, natomiast dane niezbędne do analizy uzyskano poprzez symulacje hydrodynamiczne w programie SWMM 5.0. Wykorzystana metodyka jest formalną procedurą doboru zmiennych objaśniających do modelu statystycznego. Jej podstawowym założeniem jest kryterium polegające na wyborze zmiennych objaśniających w taki sposób, aby były one silnie skorelowane ze zmienną objaśnianą, a słabo skorelowane pomiędzy sobą.
\end{abstract}

Słowa kluczowe: zbiornik retencyjny, wskaźnik pojemności informacyjnej Hellwiga, modelowanie hydrodynamiczne, korelacja, czułość modelu.

\section{Wprowadzenie}

Obserwowany w ostatnich latach istotny wzrost stopnia uszczelnienia terenów miejskich skutkuje zwiększaniem objętości ścieków opadowych kierowanych do systemów kanalizacyjnych $[1,2,6,8]$. Efektem tego niekorzystnego zjawiska jest zwiększenie natężenia przepływu strumienia objętości ścieków

\footnotetext{
${ }^{1}$ Autor do korespondencji / corresponding author: Kamil Błażej Pochwat, Politechnika Rzeszowska, Zakład Infrastruktury i Ekorozwoju, al. Powstańców Warszawy 6, 35-959 Rzeszów; tel.: 177432409; kp@prz.edu.pl

${ }^{2}$ Daniel Słyś, Politechnika Rzeszowska, Zakład Infrastruktury i Ekorozwoju, al. Powstańców Warszawy 6, 35-959 Rzeszów; tel.: 178651784; daniels@ prz.edu.pl
} 
w sieciach kanalizacyjnych [4], co wymaga ciągłych modernizacji tego systemu i dostosowywaniu go do nowych warunków hydraulicznych przepływu [12]. Bardzo często wymagane jest stosowanie urządzeń okresowo magazynujących nadmiar wód deszczowych, wśród których najważniejszymi są zbiorniki retencyjne $[3,5]$.

Dużym problemem związanym z wykorzystaniem obiektów retencyjnych jest właściwe wyznaczenie ich niezbędnej pojemności retencyjnej $V u$ [13]. Obecnie dostępnych jest wiele procedur, które wykorzystuje się przy projektowaniu zbiorników retencyjnych, które pozwalają na pozyskanie bardzo wiarygodnych wyników pod warunkiem wykorzystania oprogramowania do modelowania hydrodynamicznego. Jednakże wymagają one budowy modelu hydrodynamicznego zlewni i systemu kanalizacyjnego, które charakteryzowane są poprzez liczną grupę parametrów hydraulicznych i hydrologicznych.

\section{Cel badań}

Celem badań jest wykonanie analizy wpływu parametrów hydraulicznych i hydrologicznych zlewni i systemu kanalizacyjnego pod względem ich istotności z punktu widzenia wymiarowania niezbędnej pojemności retencyjnej zbiornika $V u$.

Wyniki analizy będą pomocne projektantom obiektów retencyjnych, ponieważ pozwolą na wyeliminowanie spośród dużej liczby parametrów hydraulicznych zlewni i systemu kanalizacyjnego tych, które nie są istotne z punktu widzenia wymiarowania zbiorników retencyjnych oraz określenie tych, które zasługują na szczególną dbałość $\mathrm{w}$ procesie projektowania. W efekcie pozwoli to na zredukowanie liczby obliczeń, które należy wykonać w celu wyznaczenia niezbędnej pojemności obiektu retencyjnego.

\section{Przedmiot badań}

Przedmiotem badań był model zbiornika retencyjnego odciążającego hydraulicznie sieć kanalizacyjną [9]. Obiekt ten jest usytuowany w systemie w osi kolektora kanalizacyjnego i charakteryzuje się następującymi parametrami projektowymi:

- niezbędna pojemność retencyjna zbiornika $V_{u}$,

- maksymalne projektowe napełnienie ściekami w zbiorniku $h_{s}$,

- powierzchnia zbiornika w rzucie $A_{1}$.

Przedstawione parametry dotyczące geometrii zbiornika zależą przede wszystkim od warunków lokalnych, w jakich funkcjonować będzie obiekt. Z kolej niezbędna pojemność retencyjna $V_{u}$ uzależniona jest przede wszystkim od warunków hydraulicznych i hydrologicznych zlewni oraz od opadu deszczu dobieranego w zależności od przyjętego stopnia bezpieczeństwa hydraulicznego funkcjonowania obiektu. 
Zgodnie z przyjętą metodyką badań [10] dokonano charakteryzacji jakościowej parametrów modelu, która polegała na sklasyfikowaniu ich w trzech zasadniczych grupach:

- parametry wejściowe do modelu (zmienne niezależne),

- parametr wyjściowy (zmienna zależna),

- parametry stałe.

Model kanalizacyjnego zbiornika retencyjnego zawierający wszystkie zmienne wejściowe (parametry niezależne), wielkość wyjściową (zmienną zależną), którą jest niezbędna pojemność retencyjna obiektu $V_{u}$ oraz stałe przedstawiono na rysunku 1.

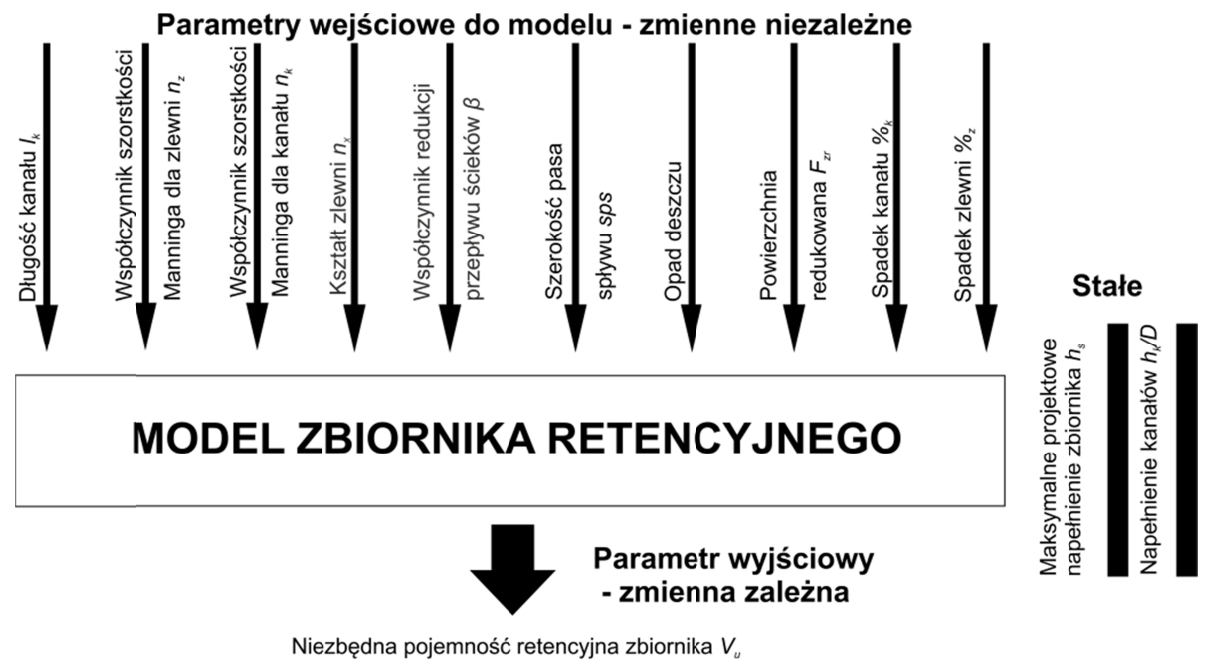

Rys. 1. Model jakościowy obiektu badań

Fig. 1. Qualitative model research object

Do parametrów niezależnych zaliczono:

- długość kanału $l_{k}$, która reprezentuje długość sieci od węzła początkowego do przekroju, w którym zlokalizowano zbiornik retencyjny,

- współczynnik szorstkości Manninga dla kanału $n_{k}$, który charakteryzuje materiał przewodu, którym przepływają ścieki,

- współczynnik szorstkości Manninga dla zlewni $n_{z}$, który charakteryzuje szorstkość powierzchni zlewni,

- kształt zlewni $n_{x}$, który określa stosunek długości boków badanej zlewni przy sprowadzeniu jej kształtu do prostokąta,

- współczynnik redukcji przepływu ścieków $\beta$, który opisuje stosunek maksymalnego strumienia objętości dopływających do zbiornika ścieków $Q A$ do strumienia objętości ich odpływu $Q A$, 
- szerokość pasa spływu sps, która jest długością, na której następuje odpływ ścieków do systemu kanalizacyjnego,

- opad deszczu w postaci zmiennej w czasie charakterystyki, opisującej zależność intensywności bądź natężenia opadu od czasu,

- powierzchnia zredukowana zlewni $F_{z r}$, która jest powierzchnią zlewni w planie po uwzględnieniu wpływu współczynnika spływu powierzchniowego zależnego m.in. od spadków zlewni - \% i sposobu jej zagospodarowania,

- spadek kanału $\%_{k}$, który opisuje różnicę wysokości pomiędzy poziomem dna kanału na jego początku, a poziomem dna na jego końcu,

- spadek zlewni $\%_{z}$, który opisuje różnicę wysokości pomiędzy poziomem terenu w części najbardziej oddalonej od kanału, a poziomem terenu przy kanale odpływowym.

Zakres wartości poszczególnych zmiennych niezależnych przyjętych do analizy przedstawiono w tabeli 1 . Ze względu na trudność w liczbowym opisie kształtu zlewni, w badaniach wprowadzono parametr $n_{x}$, który opisuje stosunek dłuższego boku zlewni do krótszego.

Tabela 1. Parametry charakteryzujące obiekt badań

Table 1 . The parameters characterizing the object of study

\begin{tabular}{|c|c|c|c|}
\hline Oznaczenie & & $\begin{array}{c}\text { Wartość } \\
\text { minimalna }\end{array}$ & $\begin{array}{c}\text { Wartość } \\
\text { maksymalna }\end{array}$ \\
\hline$F_{z r}$ & $\begin{array}{l}\text { Powierzchnia zredukowana } \\
\text { zlewni }\end{array}$ & 0 & 50 ha \\
\hline$O$ & Opad deszczu & \multicolumn{2}{|c|}{ Parametr badany } \\
\hline$S_{p s}$ & Szerokość pasa spływu & $200 \mathrm{~m}$ & $4000 \mathrm{~m}$ \\
\hline$\beta$ & $\begin{array}{l}\text { Współczynnik redukcji } \\
\text { przepływu }\end{array}$ & 0,1 & 0,9 \\
\hline$n_{x}$ & Kształt zlewni & 1 & 8 \\
\hline$n_{k}$ & $\begin{array}{l}\text { Współczynnik szorstkości } \\
\text { kanału }\end{array}$ & $0,008 \mathrm{~s} / \mathrm{m}^{1 / 3}$ & $0,013 \mathrm{~s} / \mathrm{m}^{1 / 3}$ \\
\hline$n_{z}$ & $\begin{array}{l}\text { Współczynnik szorstkości } \\
\text { zlewni }\end{array}$ & $0,013 \mathrm{~s} / \mathrm{m}^{1 / 3}$ & $0,04 \mathrm{~s} / \mathrm{m}^{1 / 3}$ \\
\hline$L_{k}$ & Długość kanału & $100 \mathrm{~m}$ & $2000 \mathrm{~m}$ \\
\hline$\%_{\mathrm{k}}$ & Spadek kanału & $1 \% 0$ & $10 \%$ \\
\hline$\%_{\mathrm{z}}$ & Spadek zlewni & $1 \%$ & $10 \%$ \\
\hline
\end{tabular}

Z kolei, do grupy parametrów stałych zaliczono:

- stosunek napełnienia ścieków w kanale do jego średnicy $\left(h_{k} / D\right)$,

- maksymalne projektowe napełnienie ścieków w zbiorniku $h_{s}$. 


\section{Założenia wstępne do analizy}

W pierwszym etapie badań pozyskano niezbędne do analizy dane, które otrzymano za pomocą symulacji przeprowadzonych z wykorzystaniem oprogramowania do modelowania hydrodynamicznego SWMM 5.0. Celem tych symulacji było określenie niezbędnej pojemności retencyjnej zbiornika $V_{u}$ dla różnych wartości parametrów hydraulicznych i hydrologicznych zlewni oraz systemu kanalizacyjnego. W tym celu wybrano reprezentatywne wartości poszczególnych parametrów wejściowych do modelu, które zestawiono w tabeli 2.

Tabela 2. Wartości zmiennych niezależnych przyjęte do analizy

Table 2. Independent variable values accepted for analysis

\begin{tabular}{|c|c|c|}
\hline Parametr & Przyjęte wartości & Jednostka \\
\hline Powierzchnia zlewni $F$ & 5 & ha \\
\hline $\begin{array}{c}\text { Współczynnik szorstkości } \\
\text { Manninga dla zlewni } n_{z}\end{array}$ & $\begin{array}{c}0,013 ; 0,015 ; 0,02 ; 0,025 ; 0,03 ; 0,035 ; \\
0,04\end{array}$ & $\mathrm{~s} / \mathrm{m}^{1 / 3}$ \\
\hline Spadek zlewni $\%_{z}$ & $1,2,3,4,5,6,7,8$ & $\% o$ \\
\hline $\begin{array}{c}\text { Współczynnik szorstkości } \\
\text { Manninga dla kanału } n_{k}\end{array}$ & 0,$008 ; 0,009 ; 0,01 ; 0,011 ; 0,012 ; 0,013$ & $\mathrm{~s} / \mathrm{m}^{1 / 3}$ \\
\hline Długość kanału $l_{k}$ & $100,250,350,500,750,1000,1500$, & $\mathrm{m}$ \\
\hline Spadek kanału $\%_{k}$ & 2000 & $\% o$ \\
\hline
\end{tabular}

Ze względu na fakt, że pojemność retencyjna zbiornika zależy przede wszystkim od powierzchni zlewni $F$, to parametr ten został wyłączony z analizy. Dodatkowo zgodnie z metodyką przedstawioną w pracy [10] z modelu wykluczono także możliwość wystąpienia zależności pomiędzy parametrami wejściowymi do modelu. W konsekwencji tego parametr opisujący szerokość pasa spływu sps został wyłączona z analizy. Wielkość ta została przyjęta zgodnie z zaleceniami instrukcji SWMM [11] i określona została jako podwojona długość kanału $l_{k}$.

\section{Metodyka badań}

Do przeprowadzenia analizy czułości modelu wykorzystano metodę wskaźników pojemności informacyjnej Hellwiga. Metoda ta pozwala na ocenę mocy korelacji parametrów wejściowych do modelu, ze zmienną zależną [7].

Zgodnie z metodologią [7], w pierwszym etapie analizy należy wyznaczyć liczbę wszystkich możliwych kombinacji potencjalnych zmiennych niezależnych. Liczba badanych układów kombinacji $L$ wyznaczana jest ze wzoru (1). 
$L=2^{m}-1$

gdzie: $L$ - liczba badanych układów, -;

$m$ - liczba zmiennych kandydujących, w tym przypadku 5, -.

W kolejnym etapie po ustaleniu całkowitej liczby kombinacji niezbędne jest opracowanie macierzy współczynników korelacji zmiennych niezależnych $R$ oraz współczynników korelacji pomiędzy zmiennymi objaśniającymi, a zmienną objaśnianą $R_{o}[7]$.

Po wyznaczeniu macierzy korelacji, dla każdego układu kombinacji należy obliczyć indywidualnie wskaźnik pojemności informacyjnej $h_{k j}$ korzystając ze wzoru (2).

$$
h_{k j}=\frac{r_{j}^{2}}{\sum_{l=1}^{m_{k}}\left|r_{l j}\right|}
$$

gdzie: $h_{k j}$ - indywidualna pojemność informacyjna, -;

$r_{j}$ - współczynnik korelacji potencjalnej zmiennej objaśniającej o nume-

rze $j$ ze zmienną objaśnianą $\left(\mathrm{R}_{\mathrm{o}}\right),-$;

$j$ - numer zmiennej w rozpatrywanej kombinacji, -;

$m_{k}-$ liczba zmiennych w $k$-tej kombinacji, -;

$r_{l j}$ - współczynnik korelacji między $I$-tą i $j$-tą potencjalną zmienną objaśniającą.

Ostatnim etapem analizy jest obliczenie integralnej pojemności informacyjnej $H_{s}$ za pomocą wzoru (3).

$$
H_{s}=\sum_{j=l} h_{k j}
$$

gdzie: $H_{s}$ - integralna pojemność informacyjna, -;

$k$ - numer kombinacji, -.

Pojemność integralna $H_{s}$-tej kombinacji jest sumą indywidualnych pojemności informacyjnych $h_{k j}$ w każdym układzie.

W interpretacji wyników należy kierować się wartością integralnej pojemności informacyjnej $H_{s}$. Im wyższy jest integralny wskaźnik $H_{s}$, tym jego układ kombinacji w większym stopniu wpływa na wynik wartości wyjściowej z modelu. Większe wartości wskaźnika integralnego $H_{s}$ wskazują na silniej skorelowane parametry niezależne z parametrem zależnym, a słabiej między sobą. 


\section{Analiza czułości modelu z wykorzystaniem wskaźnika pojemności informacyjnej Hellwiga}

Badania rozpoczęto od wyznaczenia macierzy współczynników korelacji $R$ pomiędzy przyjętymi parametrami niezależnymi. Istotna jest tutaj analiza uzyskanych w tej części wyników ze względu na możliwość wystąpienia powiązań pomiędzy poszczególnymi parametrami niezależnymi. Wyniki obliczeń przestawiono w tabeli 3. Wskazują one, że największa wartość współczynnika korelacji $r$ Pearsona występuje pomiędzy spadkiem kanału $\%_{k}$ a spadkiem zlewni $\%_{z}$ i jest ona mniejsza od 0,1 , co wskazuje na brak występowania zależności pomiędzy parametrami wejściowymi modelu. W tabeli 3 znajdują się również wartości macierzy Ro, które opisują korelacje pomiędzy badanymi parametrami niezależnymi a parametrem zależnym.

Tabela 3. Macierz korelacji zmiennych niezależnych i zmiennej zależnej

Table 3. The correlation matrix of the independent variables and the dependent variable

\begin{tabular}{|c|c|c|c|c|c|c|}
\hline & \multicolumn{5}{|c|}{ Macierz współczynników korelacji $\boldsymbol{R}$} & \multirow[b]{2}{*}{ 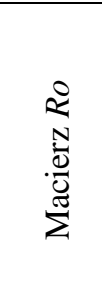 } \\
\hline & 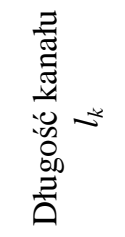 & 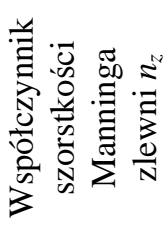 & 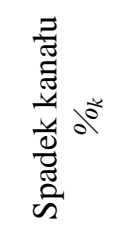 & 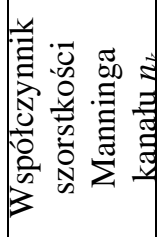 & 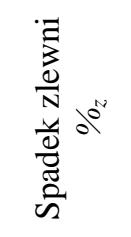 & \\
\hline Długość kanału $l_{k}$ & 1,0000 & $-0,099$ & $-0,0361$ & 0,0000 & $-0,0707$ & $-0,252$ \\
\hline $\begin{array}{l}\text { Współczynnik szorst- } \\
\text { kości Manninga } \\
\text { zlewni } n_{z}\end{array}$ & $-0,0993$ & 1,000 & $-0,0314$ & 0,0000 & $-0,0613$ & 0,954 \\
\hline Spadek kanału $\%_{k}$ & $-0,0361$ & $-0,031$ & 1,0000 & 0,0000 & $-0,0223$ & 0,016 \\
\hline $\begin{array}{c}\text { Współczynnik szorst- } \\
\text { kości Manninga } \\
\text { kanału } n_{k}\end{array}$ & 0,0000 & 0,000 & 0,0000 & 1,0000 & 0,0000 & $-0,115$ \\
\hline Spadek zlewni $\%_{z}$ & $-0,0706$ & $-0,0613$ & $-0,0223$ & 0,0000 & 1,0000 & 0,089 \\
\hline
\end{tabular}

Wyniki obliczeń wskaźnika pojemności informacyjnej Hellwiga zestawiono $\mathrm{w}$ tabeli 4 . W zastosowanej numeracji $x$ oznacza parametr niezależny, a przyporządkowana liczba wskazuje na jego rodzaj:

- $x l$-długość kanału $l_{k}$,

- $x 2$ - współczynnik szorstkości zlewni $n_{z}$,

- $x 3$ - spadek kanału $\%$,

- $x 4$ - współczynnik szorstkości kanału $n_{k}$,

- $x 5$ - spadek zlewni $\%_{z}$. 
Tabela 4. Wyniki analizy pojemności informacyjnej Hellwiga

Table 4. Results of the analysis information capacity of Hellwig

\begin{tabular}{|c|c|c|c|c|}
\hline \multirow{2}{*}{$\begin{array}{c}\begin{array}{c}\text { Numer } \\
\text { kombinacji }\end{array} \\
1 \\
\end{array}$} & \multirow{2}{*}{$\begin{array}{c}\begin{array}{c}\text { Kombinacja } \\
\text { zmiennych } \\
\text { niezależnych }\end{array} \\
x 1 \\
\end{array}$} & \multicolumn{2}{|c|}{$\begin{array}{l}\text { Indywidualne pojemności } \\
\text { nośników informacji } h_{k j} \\
\text { dla poszczególnych kombinacji } \\
\text { zmiennych niezależnych }\end{array}$} & \multirow{2}{*}{$\begin{array}{c}\begin{array}{c}\text { Integralna } \\
\text { pojemność } \\
\text { nośników }\end{array} \\
\text { informacji } \boldsymbol{H}_{\boldsymbol{s}} \\
0,0636 \\
\end{array}$} \\
\hline & & $h 01$ & 0,06357 & \\
\hline 2 & $x 2$ & $h 22$ & 0,9109 & 0,9109 \\
\hline 3 & $x 3$ & $h 33$ & 0,00026 & 0,0003 \\
\hline 4 & $x 4$ & $h 44$ & 0,01321 & 0,0132 \\
\hline 5 & $x 5$ & $h 55$ & 0,00809 & 0,0081 \\
\hline \multirow[t]{2}{*}{6} & $x 1, x 2$ & $h 61$ & 0,05783 & 0,8864 \\
\hline & & $h 62$ & 0,82861 & \\
\hline \multirow[t]{2}{*}{7} & $x 1, x 3$ & $h 71$ & 0,06135 & 0,0616 \\
\hline & & $h 73$ & 0,00025 & \\
\hline \multirow[t]{2}{*}{8} & $x 1, x 4$ & $h 81$ & 0,06357 & 0,0768 \\
\hline & & $h 84$ & 0,01321 & \\
\hline \multirow[t]{2}{*}{9} & $x 1, x 5$ & $h 91$ & 0,05938 & 0,0669 \\
\hline & & $h 95$ & 0,00755 & \\
\hline \multirow[t]{2}{*}{10} & $x 2, x 3$ & $h 02$ & 0,88319 & 0,8834 \\
\hline & & $h 03$ & 0,00025 & \\
\hline \multirow[t]{2}{*}{11} & $x 2, x 4$ & $h 12$ & 0,9109 & 0,9241 \\
\hline & & $h 14$ & 0,01321 & \\
\hline \multirow[t]{2}{*}{12} & $x 2, x 5$ & $h 22$ & 0,8583 & 0,8659 \\
\hline & & $h 25$ & 0,00762 & \\
\hline \multirow[t]{2}{*}{13} & $x 3, x 4$ & $h 33$ & 0,00026 & 0,0135 \\
\hline & & $h 34$ & 0,01321 & \\
\hline \multirow[t]{2}{*}{14} & $x 3, x 5$ & $h 43$ & 0,00026 & 0,0082 \\
\hline & & $h 45$ & 0,00791 & \\
\hline \multirow[t]{2}{*}{15} & $x 4, x 5$ & $h 54$ & 0,01321 & 0,0213 \\
\hline & & $h 55$ & 0,00809 & \\
\hline \multirow[t]{3}{*}{16} & $x 1, x 2, x 3$ & $h 61$ & 0,05599 & 0,8619 \\
\hline & & $h 62$ & 0,80562 & \\
\hline & & $h 63$ & 0,00025 & \\
\hline \multirow[t]{3}{*}{17} & $x 1, x 2, x 4$ & $h 71$ & 0,05783 & 0,8996 \\
\hline & & $h 72$ & 0,82861 & \\
\hline & & $h 74$ & 0,01321 & \\
\hline
\end{tabular}


Badania czułości modelu zbiornika retencyjnego...

Tabela 4. Wyniki analizy pojemności informacyjnej Hellwiga (cd.)

Table 4. Results of the analysis information capacity of Hellwig (cd.)

\begin{tabular}{|c|c|c|c|c|}
\hline 18 & $x 1, x 2, x 5$ & $h 81$ & 0,05434 & 0,83943 \\
\hline & & $h 82$ & 0,78486 & \\
\hline & & $h 85$ & 0,00023 & \\
\hline \multirow[t]{3}{*}{19} & $x 1, x 3, x 4$ & $h 91$ & 0,06595 & 0,0794 \\
\hline & & $h 93$ & 0,00027 & \\
\hline & & $h 94$ & 0,01321 & \\
\hline \multirow[t]{3}{*}{20} & $x 1, x 3, x 5$ & $h 201$ & 0,07116 & 0,08 \\
\hline & & $h 203$ & 0,00029 & \\
\hline & & $h 205$ & 0,00859 & \\
\hline \multirow[t]{3}{*}{21} & $x 1, x 4, x 5$ & $h 211$ & 0,0684 & 0,0903 \\
\hline & & $h 214$ & 0,01321 & \\
\hline & & $h 215$ & 0,0087 & \\
\hline \multirow[t]{3}{*}{22} & $x 2, x 3, x 4$ & $h 222$ & 0,94039 & 0,95387 \\
\hline & & $h 223$ & 0,00027 & \\
\hline & & $h 224$ & 0,01321 & \\
\hline \multirow[t]{3}{*}{23} & $x 2, x 3, x 5$ & $h 232$ & 1,0039 & 1,013 \\
\hline & & $h 233$ & 0,00028 & \\
\hline & & $h 235$ & 0,00882 & \\
\hline \multirow[t]{3}{*}{24} & $x 2, x 4, x 5$ & $h 242$ & 0,97036 & 0,99218 \\
\hline & & $h 244$ & 0,01321 & \\
\hline & & $h 245$ & 0,00861 & \\
\hline \multirow[t]{3}{*}{25} & $x 3, x 4, x 5$ & $h 253$ & 0,00027 & 0,02175 \\
\hline & & $h 254$ & 0,01321 & \\
\hline & & $h 255$ & 0,00827 & \\
\hline \multirow[t]{4}{*}{26} & $x 1, x 2, x 3, x 4$ & $h 261$ & 0,07353 & 1,13484 \\
\hline & & $h 262$ & 1,04782 & \\
\hline & & $h 263$ & 0,00028 & \\
\hline & & $h 264$ & 0,01321 & \\
\hline \multirow[t]{4}{*}{27} & $x 1, x 2, x 4, x 5$ & $h 271$ & 0,07658 & 1,18427 \\
\hline & & $h 272$ & 1,08516 & \\
\hline & & $h 274$ & 0,01321 & \\
\hline & & $h 275$ & 0,00932 & \\
\hline
\end{tabular}


Tabela 4. Wyniki analizy pojemności informacyjnej Hellwiga (cd.)

Table 4. Results of the analysis information capacity of Hellwig (cd.)

\begin{tabular}{|l|l|l|l|l|}
\hline 28 & $x 1, x 2, x 3, x 5$ & $h 281$ & 0,08006 & 1,21719 \\
\hline & & $h 282$ & 1,12728 & \\
\hline & & $h 283$ & 0,00029 & \\
\hline & & $h 285$ & 0,00956 & \\
\hline & $x 1, x 3, x 4, x 5$ & $h 291$ & 0,07116 & 0,09357 \\
\hline & & $h 293$ & 0,00028 & \\
\hline & & $h 294$ & 0,01321 & \\
\hline & & $h 295$ & 0,00891 & \\
\hline & $x 2, x 3, x 4, x 5$ & $h 302$ & 1,0039 & 1,02621 \\
\hline & & $h 303$ & 0,00028 & \\
\hline & & $h 304$ & 0,01321 & \\
\hline & & $h 305$ & 0,00882 & \\
\hline & $x 1, x 2, x 3, x 4, x 5$ & $h 311$ & 0,08006 & 1,2304 \\
\hline & & $h 312$ & 1,12728 & \\
\hline & & $h 313$ & 0,00029 & \\
\hline & & $h 314$ & 0,01321 & \\
\hline & & $h 315$ & 0,00956 & \\
\hline
\end{tabular}

Uzyskane wyniki badań wskazują, że najwyższa wartość integralnej pojemności nośników informacji $H_{s}$ uzyskała kombinacja zawierająca wszystkie zmienne (numer kombinacji: 31). Wynika z tego, że każdy z analizowanych parametrów wpływa na niezbędną pojemność retencyjną zbiornika $V_{u}$. Dalsza część analiza polegała na zidentyfikowaniu kolejnego numeru kombinacji charakteryzującego się wysoką wartością $H s$. Niewiele niższą wartością integralnej pojemności nośników informacji $H_{s}$ charakteryzowała się konfiguracja 28 , która nie zawiera współczynnika szorstkości Manninga dla kanału $n_{k}$. Stąd wniosek, że ten parametr $\mathrm{w}$ najmniejszym stopniu wpływa na niezbędną pojemność retencyjną zbiornika spośród pozostałych badanych parametrów wejściowych do modelu.

\section{Podsumowanie}

Przeprowadzona analiza wskaźnika pojemności informacyjnej Hellwiga dla modelu kanalizacyjnego zbiornika retencyjnego pozwoliła na określenie tych parametrów wejściowych do modelu, które w największym i najmniejszym stopniu wpływają na niezbędną pojemność retencyjną zbiornika $V_{u}$.

Zgodnie z zaprezentowanymi danymi, parametrem, który w największym stopniu posiadał wpływ na niezbędną pojemność retencyjną zbiornika $V_{u}$ była 
długość sieci kanalizacyjnej $l_{k}$. Parametr ten znalazł się we wszystkich numerach kombinacji zawierających wysokie wartości $H s$.

Natomiast parametrem, który w najmniejszym stopniu wpływał na wynik niezbędnej pojemności retencyjnej zbiornika był współczynnik szorstkości Manninga kanału $n_{k}$, który można uznać za nieistotny w procedurze wyznaczania niezbędnej pojemności retencyjnej zbiorników retencyjnych.

Końcowym wnioskiem wynikającym z wykonanych analiz jest stwierdzenie, że spośród badanych parametrów wejściowych do modelu największy wpływ na kubaturę obiektu ma długość kanałów $l_{k}$, a najmniejszy współczynnik szorstkości Manninga $n_{k}$.

\section{Literatura}

[1] Andrieu H., Fletcher T.D., Hamel P.: Understanding, management and modelling of urban hydrology and its consequences for receiving waters: A state of the art. Advances in Water Resources, vol. 51 no. 1, 2013, pp. 261-279.

[2] Bornatici L., Ciaponi C., Papiri S.: Control of urban runoff stormwater discharge to receiving waters using off-line storage. In Daniel Sztruhar, Mario Giulianelli, Ben Urbonas editors. Enhancing Urban Environment by Environmental Upgrading and Restoration, Kluwer Academic Publishers, The Netherlands 2004, pp. 33-44.

[3] Calabrò P.S., Viviani G.: Simulation of the operation of detention tanks. Water Research, vol. 40, 2003, no 1, pp. 83-90.

[4] Czarniecki D., Słyś D.: Analiza techniczna i finansowa wariantów ogrzewania wody z wykorzystaniem pomp ciepła współpracujących z systemami rozsączania wody deszczowej w produkcji roślinnej, Czasopismo Inżynierii Lądowej, Środowiska i Architektury JCEEA, z. 61 (3/I), 2014, s. 33-51.

[5] Douglas N.I.: On-site stormwater detention: Improved implementation techniques for runoff quantity and quality management in Sydney. Water Science and Technology, vol. 32, 1995, no 1, pp. 85-91.

[6] Dziopak J. Starzec M., Aleksejev M.I.: Effect of the sewer basin increasing to necessary useful capacity of multichamber impounding reservoir. Water \& Ecology, vol. 1, no 2, 2015, pp. 13-22.

[7] Hellwig Z.: Problem optymalnego wyboru predykant, Przegląd Statystyczny, nr 3-4, 1968, s. 223.

[8] Kordana S., Słyś D.: Analiza kosztów cyklu życia skrzynek rozsączających, Czasopismo Inżynierii Lądowej, Środowiska i Architektury JCEEA, z. 61 (3/I), 2014, s. $127-139$.

[9] Pochwat K.: Retencja wód opadowych w małych zlewniach miejskich, Politechnika Rzeszowska im. Ignacego Łukasiewicza, Wydział Budownictwa, Inżynierii Środowiska i Architektury, rozprawa doktorska, promotor: dr hab. inż. Słyś D., Rzeszów 2015.

[10] Polański Z.: Planowanie doświadczeń w technice, Wydawnictwo PWN, Warszawa 1984. 
[11] Rossman Lewis A.: Storm water management model User's manual version 5.0. dla EPA/600/R-05/040, Cincinnati 2010, pp. 1-285.

[12] Słyś D., Stec A., Effect of development of the town of Przemyśl on the operation of its sewerage system, Ecological Chemistry and Engineering S, no. 20(2), 2013, pp. 381-396.

[13] Yao-Ming Hong. Graphical estimation of detention pond volume for rainfall of short duration. Journal of Hydroenvironment, vol. 2, no 2, 2008, pp. 109-117.

\section{RESEARCH OF THE SENSITIVITY OF STORAGE RESERVOIR WITH THE USE INDICATOR OF HELLWIG INFORMATION CAPACITY}

\section{S u m m a r y}

Designing of the storage reservoirs is a complex engineering task. It requires gathering detailed Hydrological data of catchments and hydraulic data of the sewer system. This data are then are analyzed in detail. Full analysis of the factors determining the necessary storage capacity of the storage reservoir often requires the development of a detailed model of the object of research, which is the storage reservoir. The article presents the results of sensitivity analyzes of storage reservoir model. Research results allowed identifying the parameters, which affect the size of the required storage capacity of the reservoir. Scheduled analyzes were based on the analysis of the indicator of Hellwig information capacity. Necessary data were obtained by hydrodynamic simulations in the SWMM 5.0. The methodology used in the research is the formal procedure of selection explanatory variables for the statistical model. Its basic assumption is selection of variables which are have a strong correlation with variable explaining and weak Correlated between each other.

Keywords: storage reservoirs, indicator of Hellwig information capacity, hydrodynamic modelling, correlation, model sensitivity.

DOI:10.7862/rb.2016.172

Przestano do redakcji: 01.05.2016 r.

Przyjęto do druku: 28.06.2016 r. 